\title{
ESTUDOS LABORATORIAIS DE INFECÇõES HUMANAS E DE BOVINOS COM VÍRUS DO GRUPO POX *
}

\author{
J. A. Mesquita ** H. Schatzmayr ***
}

Os autores descrevem estudos laboratoriais de infecçóes bovinas e humanas após vacinação anti-variolica em comunidade rural, tendo sido isolada uma amostra de virus vaccinico de $u m$ dos animais infectados. Essa amostra foi reisolada de material original mantido a-20 $0^{\circ} \mathrm{C}$ identificada pelas lesões de membranas cório-alantóicas, provas de precipitação em agar-gel e reações sorológicas, nas quais a amostra isolada serviu de antigeno.

Estudos sorológicos comparados colm sôros padróes imunes, mostraram a presença de anticorpos inibidores da hemaglutinação e fixadores de complemento, usando-se antigenos padronizados de vírus vaccínico, evidenciando-se assim uma infeccão recente por virus do grupo Pox.

Os dois casos humanos, verificados em individuos não vacinados originaram-se muito provavèlmente dos animais, pela análise dos dados disponiveis e pela localizaçấo das lesóes observadas.

Os autores discutem ainda a possivel ação dos contaminantes presentes nos materiais sôbre os virus do grupo Pox.

Infecções com vírus do chamado grupo Pox, atingindo sêres humanos e bovinos; constituem a própria base do desenvolvimento das vacinas antivariolicas e são exemplo para o estudo das cadeias epidemiológicas na natureza. Com a intensificação das campanhas de vacinação antivariolica porém, tem sido verificada ocasionalmente, a infecção de bovinos por intermédio de indivíduos vacinados contra a varíola $(5,6,8)$. Nêste trabalho relatamos os resultados cbtidos no estudo laboratorial de uma epizootia bovina, com infecçōes humanas desenvolvidas provàvelmente a partir dos animais.

Os estudos aqui apresentados foram realizados no Laboratório de Vírus Vesiculares da FENSP, o qual recebe material, para diagnóstico de casos suspeitos de varíola, de várias partes do Brasil, através da Campanha de Erradx zção da Variola.

\section{MATERIAL E MÉTODOS}

a) Origem dos casos estudados: Os animais infectados pertenciam à uma fazenda situada no Município de Barra do Piraí, Estado do Rio de Janeiro. Quando de nossa visita à referida fazenda, encontramos grande número de vacas em lactação, com lesões restritas ao úbere, já em fase de cicatrização final. As. crostas eram de ta-

* - Trabalho do Departamento de Ciências Biológicas da Fundaçăo Ensino Especializado de Saúde Pública (FENSP) apresentado em resumo n o XII Congresso Brasilelro de Medicina Veterinária, em Dezembro de 1968.

* - Virologista, Laboratório de Vírus Vesiculares, FENSP, Caixa Postal 16, ZC-24, Rio de Janeiro Guanabara.

*.* - Professor-adjunto, responsável pelos Laboratórios de Vírus da FENSP. 
manhos irregulares, notando-se a confluência de várias lesōes. (Fig. 1). Os dois casos humanos observados ccrrespondiam a dois ordenhadores, os quais desenvolveram lesões na palma das mãos e entre os dedos, sob a forma de vesiculas em pequeno número, dolorcsas, e que evcluíram sem maior gravidade. Não foram observades sintomas gerais importantes nos casos humanos nem nos animais.

b) Coleta de material: A coleta de material cos animais fci realizada com pinças e frascos esterilizados, de 10 animais escolhidos ao acaso, dentre aqueles que apresentavam crostas removiveis com relativa facilidade. Não foi colhido material das lesōes dos casos humanos, porque as vesículas já haviam sido drenadas e tratadas com antissépticos locais. Foi coletado sangue por punção venosa, dos mesmos dez animais e dos dois ordenhadores, separando-se posteriormente o sòro, o qual foi congelado a $-20^{\circ} \mathrm{C}$.

c) Isolamento de virus: o material coletado foi trabalhado por técnicas de rotina no nosso Laboratório. As crostas, trituradas em solução salina tampcnada e com antibióticos; as suspensões assim obtidas, inoculadas em memuranas corioalantóicas (MCA) de ovos embrionados de 11 dias, $0,1 \mathrm{ml}$ por ôvo e após 48-60 horas de incubação a $36^{\circ} \mathrm{C}$, os ovcs foram abertos e as membranas examinadas.
A forte contaminação bacteriana, presente no material de crostas, provocou a morte dos embriōes, nos primeiros cinco espécimes examinados, cbrigando a tratamentos mais prolongados com antibióticos ( 24 horas a $4^{\circ} \mathrm{C}$ ) e o uso de Freon 113 (4), na proporção de 1 parte dêste para 10 partes da suspensão de crostas.

d) Reação de precipitação em ágar: Foram usadas, essencialmente, técnicas já descritas, utilizando-se Special Agar-Noble (Difco) a $1 \%$ em água destilada, sôbre lâmina. Antígenos positivos (suspensão de MCA ricamente infectadas com vírus vaccinicol e sôro antivaccínico padrão (origem: NCDC, Atlanta, Georgia, USA), foram usados nos cortrôles juntamente com o sôro normal de coelho (3).

e) Reação sorológicas: As provas de fixação de complemento e de inibição da hemaglutinação foram realizadas usando-se 2 e 4 unidades, respectivamente, de antigeno preparado a partir de MCA infectadas, segundo técnicas padronizadas.

\section{RESULTADOS}

1) Isolamento e identificação do vírus: Do material de um dos animais, foi isolada uma amostra de virus, produzindo tipicas lesões de virus vaccínico (fig. 2) nas membranas corioalantóicas (amostra n. 10261

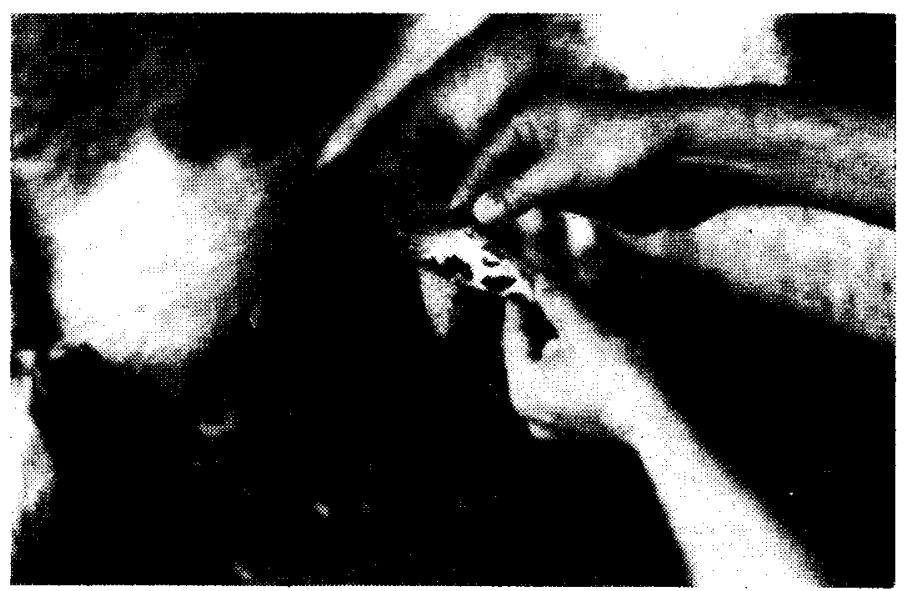

Figura 1: Lesóes confluentes, em fase de crostas, na ocasião da coleta de material dos animais 


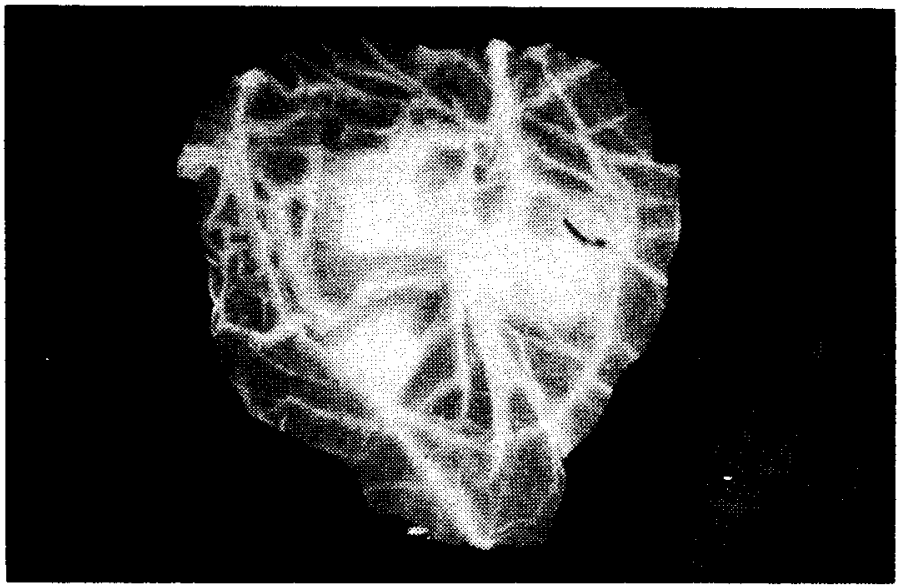

Fi̊nura 2: Lesōes na membrana corio-alantóica. Embriōes inocu lados com 11 dias de idade e coletados após 60 horas.

A amostra póde ser reisolada de material criginal mantido a-20 . Êsse material, reinoculado em ovos embrionados, deu igualmente prigem a lesōes típicas de vírus vaccínico em MCA. Essa amostra foi ainda identificada como do grupo Pox, por provas de precipitação em agar-gel, fixação de ccmplemento e inibição da hemaglutinação. Foram feitas passagens em ovos embrionados, e na $3^{\text {* }}$ passagem a amostra isolada alcançou o título de $17 \mathrm{x}$ $10^{8}$ lesões/ml em MCA.

A possibilidade de tratar-se de uma infecção pelo chamado vírus do "“cow-pcx", o qual por coincidência tivesse surgido na região logo após a vacinação anti-variolica realizada algumas semanas antes, foi descartada pelos resuitados laboratcriais, aqui descritos, além dos dados epidemiclógicos disponíveis. Medidas profiláticas já haviam circunscrito a doença apenas aos currais onde ela se manifestou apesar de, em sua evolução rápida, ter atin- gido grande número de animais em curto praze.

2) Provas sorológicas: Os sôros animais e humanos foram incluídos em provas de fixação dc complemento e inibição da hemaglutinação (Tabela anexa)

Podemos verificar a presença de anticcrpos nos sôros examinados, indicando uma infecção por um vírus do grupo Pox, embora, como é conhecido, essas provas não possuam caráter de especificidade, que permita identificar os membros dêsse grupo de vírus, entre si.

\section{DISCUSSÃO}

O nosso país constitui, infelizmente, ainda, o grande foco endêmico de variola na América do Sul, com 3109 casos notificados neste ano até 7 de dezembro de 1968 (1).

o notável incremento das vacinaçōes humanas propiciou o aprimoramento de

PROVAS SOROLÓGICAS

INIBIÇÃO DA HEMAGLUTINAÇÃO E FIXAÇÃO DO COMPLEMENTO

\begin{tabular}{|c|c|c|c|c|c|c|c|c|c|c|c|c|}
\hline \multirow{2}{*}{ POROVA } & \multicolumn{5}{|c|}{ Sôros } & \multicolumn{5}{|c|}{ bcvinos } & \multicolumn{2}{|c|}{ S. humanos } \\
\hline & 1021 & 1022 & 1023 & 1024 & 1025 & 1026 & 1027 & 1028 & 1029 & 1030 & 1032 & 1033 \\
\hline $\begin{array}{l}\text { In. Hem. } \\
\text { F. C. }\end{array}$ & $\begin{array}{l}\S \S \\
40 \\
40\end{array}$ & $\begin{array}{r}160 \\
40\end{array}$ & $\begin{array}{r}160 \\
20\end{array}$ & $\begin{array}{l}20 \\
\mathrm{AC}\end{array}$ & $\begin{array}{l}160 \\
\mathrm{AC}\end{array}$ & $\begin{array}{r}320 \\
40\end{array}$ & $\begin{array}{l}20 \\
80\end{array}$ & $\begin{array}{r}320 \\
20\end{array}$ & $\begin{array}{l}80 \\
40\end{array}$ & $\begin{array}{r}320 \\
40\end{array}$ & $\begin{array}{l}160 \\
320\end{array}$ & $\begin{array}{l}160 \\
320\end{array}$ \\
\hline
\end{tabular}

$\$$ - Antígenos preparados à partir de MCA infectados com vírus vaccínico.

$\$ \S$ - Recíproca da diluição do sôro.

AC - Soros anticomplementares. 
técnicas, dispondo-se atualmente de vacinas de alto título e de métodos de vacinação em massa, com pistolas injetoras. Com isto, temos hoje a disseminação em curtc prazo, de grandes quantidades de vírus vaccínico, com possibilidade de atin-gir bovinos quando do processo de ordenha, ccmo é mostrado neste trabalho, e ainda a contaminação reversa, com casos humanos a partir dos animais.

A grande dificuldade de isolamento de virus a partir das crostas de bovino pela presença de contaminantes foi superada pelo uso de Freon 113 com técnicas semelhantes às usadas para a purificação de vacinas antivaríolicas. Tal procedimento apresentou excelentes resultados em nossas mãos.

Segundo Mayr (7), os anticorpos fixadores do complemento para o vírus vaccinico em bovinos, aparecem em baixo titulo ou mesmo não são detectáveis. Foi possivel confirmar essa observação, nos sôros bcvinos estudados, enquanto que os sôros humanos apresentaram títulos elevados (Tabela anexa).

Os anticorpos anti-hemaglutinantes desenvolveram-se em baixo título, em dois animais, por razões não definidas. Sabemos que, em alguns indivícuos já vacinados, tendo pois desenvclvido uma infecção pelo vírus vaccínico, uma segunda vacinacão promove resposta deficiente de anticorpos inibidores da hemaglutinação. Sôbre a presença de infecçäo anterior com vírus do grupo Pcx, nos animais estudados, não há dados disponíveis, embora a hipótese não possa ser afastada.

Devemos assinalar que as epizootias pelo vírus vaccínico, assumem via de regra, um caráter de disseminação rápida entre os animais, ao contráric das infecções pelo virus do chamado "cow-pox" que evoluem mais lentamente e, via de regra, se disseminam em menor velocidade. Constituem, porèm, as provas laboratoriais de isolamento e identificação de virus, um dado fundamental e indispensável no esclarecimento de epizootias do tipo aqui estudado. Os dados epidemiológicos e clínicos sãc, dentro do grupo Pox, especialmente em relação aos vírus da vaccínia e do chamado "cow-pox", próximos e mesmo coincidentes, não permitindo diagnóstico diferencial seguro.

A presença de contaminantes, que é a regra em todo material enviado ao laboratório para diagnóstico de infecçōes pelo grupo Pox, tem segundo Dostal et col. (2) um papel importante, através de suas enzimas proteoliticas e lipolíticas. Estes autores mostraram que enzimas bacterianas têm uma ação sôbre o envoltório dos virus Pox, especialmente vaccínia. Acreditamos perfeitamente possível que o isolamento de apenas uma amostra de vírus a partir de material de 10 animais, todos na mesma fase de evoluçāo tenha sido influenciado pelos contaminantes presentes; devemos acrescentar que, nos materiais de origem humana por nós recebidos para diagnóstico, raramente observamos mortes de embriōes por contaminação, mesmo após tratamento simplesmente com pen:cilina e estreptomicina. Estes fatos talvez devam ser considerados quando tivermos resultados negatives nas tentativas de isolamento de vírus a partir de material fortemente contaminado.

\section{AGRADECIMENTOS}

Os autores agradecem à direção da Campanha de Erradicação da Varíola que ncs proporcionou facilidades para a realizaçāo do trabalho bem como ao veterinário Dr. Camillo F. C. Canella que colakorou nas coletas de material e obtenção de dados disponiveis sôbre os animais.

\section{SUMMARY}

The authors describe the isolation and identification of vaccinia virus from a cow in farm where human vaccination had been carried out some weeks before. Many of the vaccinated peopie had developed typical vaccine reaction and had been in close contact with the animals. Two human cases with lesions on hands, have been observed in not vaccinated farm employees; unfortunately the lesions from these human cases were already open and washed with local antisseptics and no attempt to isolate virus could be done. 
The infection disseminates very rapidly among the animals but no severe symptoms have been observed neither in the animals, nor in the two human cases.

The isolated strain has been identified by serological tests (complement fixation and $\mathrm{HI}$ tests) and lesions on the corio-alantoic (fig. 2) of embryonated eggs; the strain could be reisolated from original material kept at minus $20^{\circ} \mathrm{C}$.

The material collected from the animals was heavily contaminated and it was necessary to use Freon 113 (1 part to 10 of the material suspension) in order to control these contaminants.

The possible action of bacterial enzymes against Pox virus in heavily contaminated materials, is discussed in relation to a recent reference in the literature.

\section{BIBLIOGRAFIA}

1 - Boletim Semanal da Campanha de Erradicação da Varíola, Tomo 2: (42), pág. 4, Semanas n.o 48 e 49,1968 2 - DOSTAL, V. \& BRANTNER, H. on the stability on vaccinia virus, Ztschr. Immunforsch., 1.34: 493-504, 1968.

3 - DUMBELL, K. R. \& NIZAMUDDIN, M. - An agar-gel precipitation test for the laboratory diagnosis of Smallpox, Lancet, 1: 916-917, 1959.

4 - EPSTEIN, M. A. - An investigation into the purifying effect of fluorccarbon on vaccinia virus, Brit. J. Exp. Med., 39: 436-446, 1958.

5 - HAEDO, A. F . Epizootía de cow-pox en el ganado lechero producido por la inoculación accidental de un hombre recientemente sometido a la vacunación antivarióíica, Arch. Urug. Med., 34 : 252-259, 1949.

6 - LUN, G. S., SORIANO, F., TRFJOS A. \& LLERENA, J., - Vaccinia epidemic and epizootic in El Salvador, Am. I. Trop. Med., 16: (3), 332-338, 1967.

7 - MAYR, A. Mikrobiologie, - (Editores: Rolle, M. \& Mayr, A.). Editora Ferdinand Enke, Stuttgart, 1966, págs. 638-639.

8 - PANDO, U. G., LOPEZ, J. H. T., RESTREPO, A. R. \& FORERO P. C., - Estudio de un brote de vaccinia en ganado lechero y sus ordeñadores. Bol. Of San. Panam., LXIII : (2), 111-121, 1967. 